\title{
Silver European eels health in Mediterranean habitats
}

\author{
Elsa Amilhat ${ }^{1,2}$, Géraldine Fazio ${ }^{3}$, Gaël Simon ${ }^{1,2}$, Marc Manetti ${ }^{1,2}$, Séverine Paris ${ }^{4}$, Laurence Delahaut ${ }^{4}$, Henri \\ Farrugi $^{5}$, Raymonde Lecomte-Finiger ${ }^{1,2}$, Pierre Sasal ${ }^{6}$, Elisabeth Faliex ${ }^{1,2}$ \\ ${ }^{1}$ University Perpignan Via Domitia, Centre de Formation et de Recherche sur les Environnements Méditerranéens, F-66860, Perpignan, France \\ ${ }^{2}$ CNRS, Centre de Formation et de Recherche sur les Environnements Méditerranéens, UMR 5110, F-66860, Perpignan, France \\ ${ }^{3}$ Independent Researcher, 47 rue des Trois Rois, 86000, Poitiers, France \\ ${ }^{4}$ Unité de recherche Interactions Animal Environnement, UFR Sciences exactes et naturelles, Université de Reims Champagne-Ardenne, \\ F-51687, Reims, France \\ ${ }^{5}$ Laboratoire Ressources Halieutiques, IFREMER, avenue Jean Monnet, BP 171, 34203, Sète, France \\ ${ }^{6}$ USR 3278 CNRS-EPHE, CRIOBE, BP 1013, Papetoai Moorea, French Polynesia
}

Accepted for publication June 3, 2013

Abstract - The degradation in the quality of silver eel and their health could have been a major factor in the collapse of the European eel (Anguilla anguilla) population. However, the health status of the spawners has been poorly studied until now. This study evaluated the quality of migrant male silver eels from four Mediterranean habitats in France presenting different degrees of contamination: Canet-Saint-Nazaire, Salses-Leucate and BagesSigean lagoons and La Berre River. We considered pathogens including Anguillicoloides crassus and EVEX virus and the concentration of chemical contaminants including PCBs, OCs and heavy metals. Our study results revealed different patterns of pollution and infection in the four habitats, with high individual variability. No single silver eel was free of pollution. Total dichloro-diphenyl-trichloroethane (DDT) and copper contaminations, as well as the Swim bladder Degenerative Index (induced by parasitism), were remarkably high in eels from Canet lagoon, while eels from Salses lagoon showed lower levels of contaminants and parasite infection. A non-negligible proportion of eels were strongly impacted with levels of contaminants/parasites that could potentially impair their migration and reproduction. Our study revealed low to moderate contamination levels compared with the other Mediterranean sites previously reported, except for high concentrations of DDTs and $\mathrm{Cu}$ in Canet lagoon. We discuss the contribution of these results in the context of possible implications for silver eels reproductive success and local eel population management.

Key words: Anguilla anguilla; Mediterranean lagoons; silver eel; contamination; spawner quality; pathogens

\section{Introduction}

Mediterranean lagoons are productive brackish habitats that sustain a high biodiversity (De Wit 2011). They maintain the important economic activity of fisheries, for which the European eel, Anguilla anguilla, represents one important targeted species. However, these ecosystems have to deal with increasing anthropogenic pressures, often being a major receptacle of pollutants, collecting a mixture of urban, industrial and agricultural contaminants from the river basin. They are also confined environments where contact between hosts and infective stages of parasites and/or viruses may be facilitated (Faliex \& Morand 1994). Due to their specific life cycle (semelparous fatty species), eels are particularly sensitive to the contaminants present in these habitats. During its long sedentary phase of 3-12 years in lagoons (Mallawa 1987; Acou et al. 2003), this benthic predator species (Persic et al. 2004) is particularly prone to lipophilic contaminant accumulation.

The European eel stock has declined since the 1960s (Dekker 2003) and is currently considered to be outside the safe biological limits. Glass eel 
recruitment is currently at its lowest level, which is 1-5\% compared with 1960-1979 levels (ICES 2012). Several reasons for the decline have been proposed including climate change, habitat loss, barriers to migration, overfishing, disease and pollution. There is, however, a recent interest in the 'quality' of silver eels and their health status as this might be a key factor in explaining the decline (Robinet \& Feunteun 2002; Pujolar et al. 2012; Maes et al. 2013). However, little research has been carried out specifically on silver eel quality in natural systems, and most research focuses on either contaminants or pathogens but not on both. One study conducted on eels from the Dutch River Rhine and Lake Ijsselmeer related to diseases, parasites, virus and bacteria (Haenen et al. 2010), and another in Italy (Garigliano River) focussed on persistent organic pollutants (POPs) (Ferrante et al. 2010). Nagel et al. (2012) studied the impact of silvering on polycyclic aromatic hydrocarbons (PAHs) metabolite concentrations in bile. Pujolar et al. (2012) looked at the effect of pollution (POPs and metals) on gene expression. Finally, Sühring et al. (2013) studied brominated flame retardants and dechloranes in silver eels from German rivers. One recent study by Quadroni et al. (2013) looked at both contamination (POPs and dioxins) and parasites in three Italian stocks (lagoons and river). Our study is unique in focussing on male silver eels.

To recover the European eel stock, the European Commission mandated each European country to adopt an Eel Management Plan (EMP) in 2007. The objective of each EMP is to 'reduce anthropogenic mortalities so as to permit with high probability the escapement to the sea of at least $40 \%$ of the silver eel biomass relative to the best estimate of escapement that would have existed if no anthropogenic influences had impacted the stock' (Council Regulation (EC) 1100/2007). This objective does not emphasise the importance of the health status of the escaping eels. The EU's objective of increasing the biomass of migrant eels has meaning only if the eels have sufficient health quality to reproduce successfully.

Although there is growing concern that the quality of the spawners is being hampered by contaminants and pathogens (Geeraerts \& Belpaire 2010), little is known about the specific effects of these contaminants on the eel reproduction, particularly in males. The complex life cycle of the eel makes this kind of research difficult, and only a few studies have attempted to measure effects of health quality on eel migration and reproduction success. Palstra et al. (2007) demonstrated using swimming tunnels that the swim bladder parasite, Anguillicoloides crassus (Kuwahara et al. 1974), significantly reduced the swimming performance of the silver eels, possibly by causing insufficient energy necessary for the transoceanic migration. Lefebvre et al. (2002) suggested that eels with severely damaged swim bladders (Swim bladder Degenerative Index $\geq 4$ ) would not be able to migrate and reproduce successfully. It was also shown, both in naturally and experimentally infected eels, that this parasite has an effect on the silvering process (Fazio et al. 2008, 2012). The rhabdovirus Eel Virus European X (EVEX) seems to be responsible for $100 \%$ impairment of the migration in swimming tunnels, with development of severe haemorrhages after $1500 \mathrm{~km}$ (van Ginneken et al. 2005). Palstra et al. (2006) reported a negative correlation between embryo survival time and 2,3,7,8-tetrachlororodibenzo-p-dioxin (TCDD) toxic equivalents (TEQs). The observed embryonic malformations were characteristic of eggs exposed to PCBs. Disrupting effects occurred at levels below 4 ng TEQ per $\mathrm{kg}$ gonad. However, the two precedent studies have been criticised because of the low sample size. Finally, Pierron et al. (2008) reported oocyte atresia and eel mortality due to cadmium concentration in liver tissue over $1.7 \mu \mathrm{g} \cdot \mathrm{g}^{-1}$ dry weight.

Anguilla anguilla is considered as a panmictic species (Als et al. 2011) and therefore as a single stock in terms of management and conservation efforts. However, the contribution to the spawning stock from different locations will depend on the quality of the spawners in different habitats. The aim of this study was to evaluate the quality of migrant silver eels from Mediterranean habitats, representing different degrees of anthropogenic stressors and environmental factors including salinity, connection to the sea and depth. We investigated the relationship between the level of contamination and parasitism and the health condition and lipid contents of the eels. The strength of this study is in considering the effects of both chemicals contaminants and pathogens on the male silver eel. The results are discussed in regard to the literature and in support of estimates of the proportion of silver eels of low quality and potentially unfit for a successful migration and reproduction.

\section{Materials and methods}

\section{Studied areas}

The lagoons of Canet-Saint-Nazaire (Canet), SalsesLeucate (Salses) and Bages-Sigean (Bages) are located on the north-west Mediterranean coast of the Gulf of Lion (Southern France) (Fig. 1). The characteristics of the three lagoons are provided in Table 1. La Berre, a 38-km-long river, is the main affluent river of Bages lagoon and drains an area of $238 \mathrm{~km}^{2}$. 


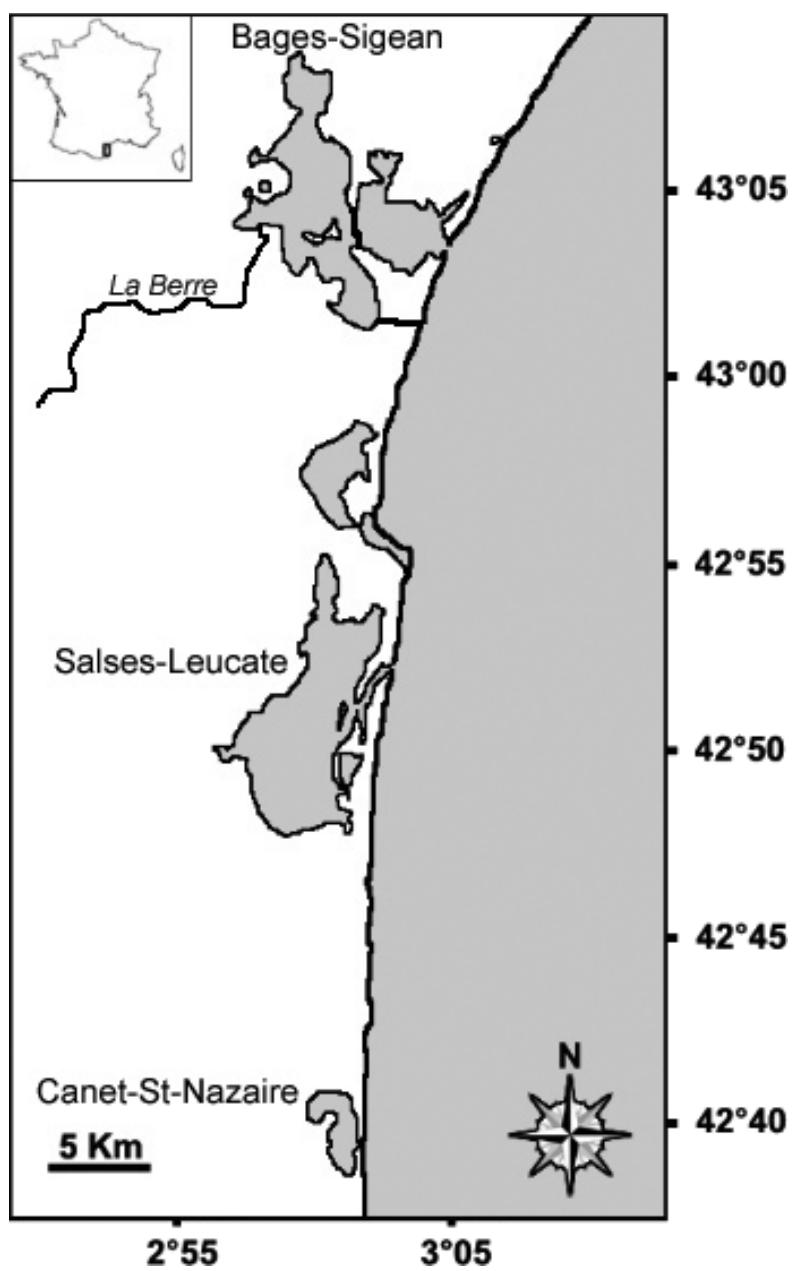

Fig. 1. Map showing the three studied lagoons and the River La Berre.

\section{Eel collection}

Samples of silver eel were collected during the migration period (October to December) by professional fishermen in the three lagoons and by ONEMA (French National Agency for Water and Aquatic Environments) in the La Berre River. The eels were randomly chosen from the fishing catches. Profes- sional fishermen in lagoons use passive gear made from three fyke nets, locally called 'capéchades', which have a 6- to 10-mm mesh size. During the migration period, fishermen set up several capéchades at strategic places to target silver eels. Nets are lifted every morning (when the weather allows it), and catches were collected until around 30 eels per sampling period were obtained. In 2007, eels were sampled in Canet (27 November-13 December) and in Bages (27 November) lagoons only. In 2008, three lagoons were sampled: Canet lagoon (31 October, 2-5 December), Bages lagoon (9-10 October, 29-30 October, 25 November) and Salses lagoon (24 October and 27 November). Eels from La Berre were collected on 25 November by electrofishing. Because the sex ratio was biased in favour of males in the three lagoons, we decided to restrict our study to the males. While 222 eels were collected, these were subsampled for the various analyses (see Tables 2-5 for individual sample sizes). Eels were brought to the laboratory alive, and dissections were performed in 1 or 2 days following their capture. Eels were anesthetised with eugenol $\left(0.1 \mathrm{ml} \cdot \mathrm{l}^{-1}\right.$ sea water). The total length $(\mathrm{Lt})$ was recorded to the nearest millimetre and the total weight $(\mathrm{W})$ to the nearest $\mathrm{g}$. Eels were then killed by decapitation. Silver stage was determined based on three criteria (Acou et al. 2005): a differentiated lateral line (the presence of black corpuscles), a contrasting colour (dark dorsal surface and a white ventral surface) and an ocular hypertrophy index OI $>6.5$ (Pankhurst 1982). Ocular index was calculated as $\mathrm{OI}=\left((\mathrm{Dh}+\mathrm{Dv} / 4)^{2} * \pi / \mathrm{Lt}\right) * 100$, where $\mathrm{Dh}$ and $\mathrm{Dv}$ are, respectively, the horizontal and vertical eye diameters and Lt the total length in millimetre.

\section{Condition of the eels}

The condition of each eel was estimated using Fulton's condition factor: $\mathrm{K}=100 . \mathrm{W}(\mathrm{g}) / \mathrm{Lt}(\mathrm{cm})^{3}$ (Ricker 1975). The hepatosomatic index (LI) and spleen index (SI) were calculated only for eels captured in

Table 1. Characteristics of the three studied lagoons: Canet-Saint-Nazaire (Ifremer 2008), Salses-Leucate (Buscail et al. 2009) and Bages-Sigean (Natural Regional Park de la Narbonnaise en Méditerranée, pers. com and Ifremer 2008). Data on estimated eel captures were deduced from fisherman log books.

\begin{tabular}{|c|c|c|c|}
\hline Parameter & Canet St-Nazaire & Salses-Leucate & Bages-Sigean \\
\hline Area $\left(\mathrm{km}^{2}\right)$ & 6 & 54 & 38 \\
\hline Average depth (m) & 0.2 & 1.2 & 1.3 \\
\hline Maximum depth (m) & 0.7 & 3.7 & 2.85 \\
\hline Estimated eel capture in tons/year & NA & 20 & 37 \\
\hline Average salinity \pm SE (min-max) & $22.3 \pm 5(4-40)$ & $33.5 \pm 3.5(28-36)$ & $32 \pm 5(22-38)$ \\
\hline River basin area $\left(\mathrm{km}^{2}\right)$ & 260 & 160 & 443 \\
\hline Connectivity with the sea & Unique opening controlled by sluices & 3 openings no sluices & Unique opening no sluices \\
\hline Anthropogenic pressures & Agriculture, viticulture, urban & Tourism, viticulture & $\begin{array}{c}\text { Agriculture, viticulture, } \\
\text { urban and industries }\end{array}$ \\
\hline
\end{tabular}

NA, no data available. 
Amilhat et al.

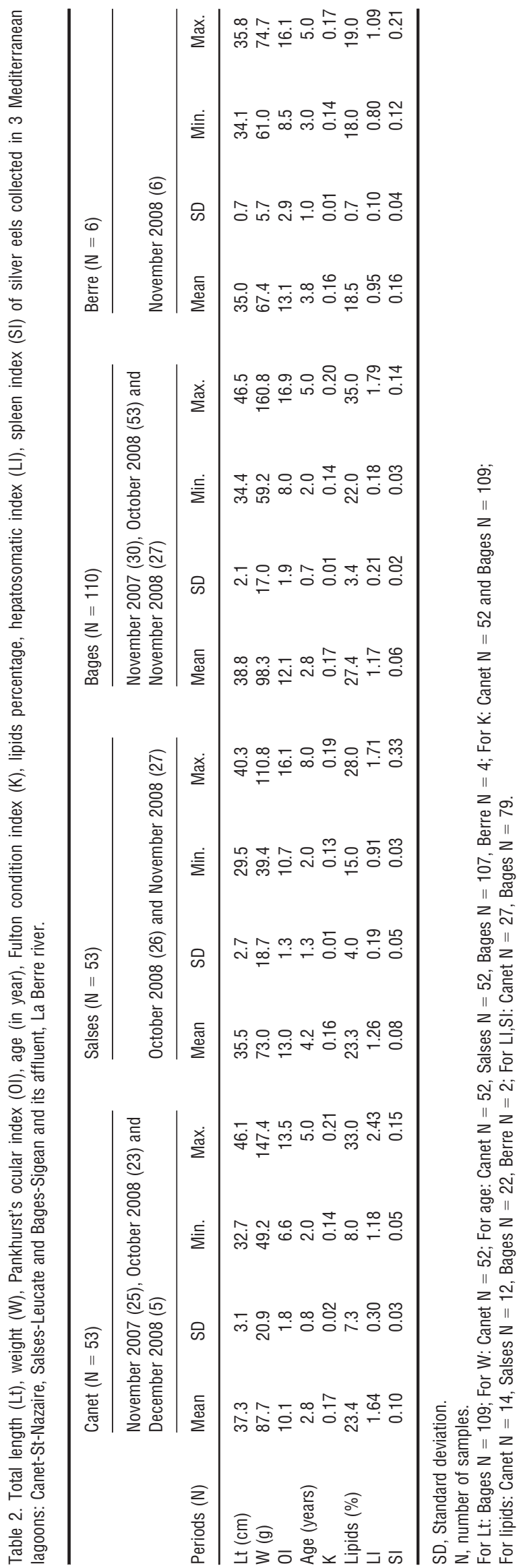

2008 as $\mathrm{LI}=100 *[$ liver weight $(\mathrm{g}) /$ somatic $\mathrm{W}(\mathrm{g})]$ and $\mathrm{SI}=100 *[$ spleen $\quad$ weight $(\mathrm{g}) /$ somatic $\mathrm{W}(\mathrm{g})]$, respectively.

\section{Age estimation}

Sagittal otoliths were removed from the head of each eel and cleaned with distilled water. Small otoliths (young eels) were examined in toto in camomile oil under stereomicroscope. For older eels (more than 4 years old) and when the reading was not clear, the otolith was embedded in resin and ground. After using an EDTA solution, otoliths were stained with toluidine blue to visualise annual rings. Age estimation was made by counting the winter rings (Lecomte-Finiger 1985; ICES 2009).

\section{Determination of heavy metals}

Metals were analysed in liver and muscle tissue of 65 eels collected in 2008 (Canet: 5; Salses: 27; Bages: 27; and Berre: 6) by the laboratory of ecotoxicology, University of Reims, France. From each individual, a sample of muscle tissue on the ventral part of the body (at equal distance between gills and the anus) was removed to conduct metal analysis. Due to laboratory limitations, we investigated three heavy metals: copper $(\mathrm{Cu})$, cadmium $(\mathrm{Cd})$ and zinc $(\mathrm{Zn})$. Fish samples were dried (weighed for dry weight) and digested by nitric acid attack (pure $\mathrm{HNO} 3$, Merck) at $70{ }^{\circ} \mathrm{C}$ for $48 \mathrm{~h}$. The residue was taken using nitric acid and diluted in water to obtain a solution containing $1 \%$ of acid. $\mathrm{Cu}$ and $\mathrm{Cd}$ concentrations were measured by atomic absorption spectrophotometry (Varian AA 240 FS) equipped with a model GTA 110 graphite tube atomiser and autosampler. The detection limit for $\mathrm{Cu}$ was $2 \mu \mathrm{g} \cdot \mathrm{l}^{-1}$ or $0.24 \mu \mathrm{g} \cdot \mathrm{g}^{-1}$ tissue (dry wt.), and for $\mathrm{Cd}$, it was $1.5 \mu \mathrm{g} \cdot \mathrm{l}^{-1}$ or $0.18 \mu \mathrm{g} \cdot \mathrm{g}^{-1}$ tissue (dry wt.). $\mathrm{Zn}$ analyses were carried out by flame atomic absorption spectrometry (Varian AA 240 FS), on the same digestates. The detection limit was $1 \mu \mathrm{g} \cdot 1^{-1}$ or $0.12 \mu \mathrm{g} \cdot \mathrm{g}^{-1}$ tissue (dry wt.). Blank and standards were run with each batch of samples. The validity of the analytical method was checked by means of two standard biological reference materials (DORM-3, protein fish; and DOLT-3, dogfish liver from NRCC-CNRC, Ottawa, Canada).

Determination of polychlorinated biphenyls (PCBs) and organochlorine pesticides (OCs)

Due to budget limitations, a low number of eels (Canet: 14; Salses: 12; and Bages: 22) were analysed for PCBs and OCs. The two eels analysed in the river $\mathrm{La}$ Berre were not included in the analysis. For each individual, the remaining part of the muscle tissue 
after sampling for metal analysis was transferred frozen to the LDA for PCBs and OCs analyses. Seven PCB indicators (CB28, CB52, CB101, CB118, CB138, CB153 and CB180) considered by the International Committee for the Exploration of the Sea (ICES) as a representative index of PCB contamination were investigated in muscle. In addition, a total of 23 persistent organochlorinated compounds were also tested for in the same tissue: HCB; $\alpha, \beta, \delta$ and $\gamma$ lindane; heptachlor; heptachlor epoxide; aldrin; dieldrin; o,p'-DDD; o,p'-DDE; p,p'-DDD; p,p'-DDE; op' DDT; p-p' DDT; endrin; cis- and trans-chlordane, oxychlordane; chlorothalonil; $\alpha$ endosulphan; $\beta$ endosulphan; and endosulphan sulphate. PCBs and OCs were analysed at the Laboratoire Départemental d'Analyses des Pyrénées Orientales (LDA 66, France) based on the reference method NF EN 1528 based on gas chromatography. The limit of detection (DL) was $4 \mathrm{ng} \cdot \mathrm{g}^{-1}$ fresh muscles for all compounds tested.

\section{Fat level determination}

The analyses of lipid contents were carried out at the LDA on the same muscle sample used for PCBs and OCs determination. Ten grams of natrium sulphate was added to a $20-\mathrm{g}$ ground eel muscle sample. The sample was mixed in order to be homogenised. Then, $50 \mathrm{ml}$ hexane was added progressively. The sample was centrifuged for $5 \mathrm{~min}$ at $1500 \mathrm{rpm}$. The supernatant was collected in a preweighed flask, and the solvent was evaporated using a rotoevaporator and then resuspended in $50 \mathrm{ml}$ hexane. The solvent was evaporated using the same rotoevaporator, leaving only lipids in the bottom of the preweighed flask, from which the total mass of lipids was determined. The fat content is expressed as a percentage of muscle wet weight ( $\mathrm{g}$ of lipids per $100 \mathrm{~g}$ of sample).

\section{Parasites examination}

The swim bladder of each eel $(n=221)$ was examined under a stereomicroscope for the presence and number of the invasive parasite A. crassus (adults, L4- and L3-stage larvae). Classical epidemiological parameters: prevalence, mean intensity and mean abundance (Bush et al. 1997) were calculated for each site. The Swim bladder Degenerative Index (SDI) represents the state of degradation of the swim bladder. It was calculated by adding the scores obtained for three criteria: opacity, the presence of pigmentation/exudate and thickness, each one coded by 0,1 or 2 , according to Lefebvre et al. (2002). The SDI may range from 0 (intact) to 6 (strongly damaged). 
Amilhat et al.

Table 4. Mean concentrations (ng. $\mathrm{g}^{-1}$ wet weight) of DDTs and PCBs in the muscle of the silver eels from Canet, Salses and Bages lagoons. Total length (Lt), weight (W), age and lipids contents are indicated for each site.

\begin{tabular}{|c|c|c|c|c|c|c|c|c|c|c|c|c|}
\hline & \multicolumn{4}{|c|}{ Canet $(N=14)$} & \multicolumn{4}{|c|}{ Salses $(N=12)$} & \multicolumn{4}{|c|}{ Bages $(N=22)$} \\
\hline & Mean & SD & Min. & Max. & Mean & SD & Min. & Max. & Mean & SD & Min. & Max. \\
\hline $\mathrm{Lt}(\mathrm{cm})$ & 37.6 & 1.4 & 35.2 & 39.8 & 36.2 & 2.5 & 32.0 & 39.7 & 39.1 & 1.3 & 36.1 & 41.7 \\
\hline W (g) & 88.5 & 9.2 & 71.0 & 109.6 & 79.7 & 21.6 & 47.0 & 110.8 & 98.5 & 10.9 & 79.0 & 117.8 \\
\hline Age (years) & 2.9 & 0.8 & 2.0 & 4.0 & 4.1 & 1.8 & 2.0 & 8.0 & 3.1 & 0.8 & 2.0 & 5.0 \\
\hline Lipids (\%) & 23.4 & 7.3 & 8.0 & 33.0 & 23.3 & 4.0 & 15.0 & 28.0 & 27.4 & 3.4 & 22.0 & 35.0 \\
\hline$p-p^{\prime} D D E$ & 273.3 & 239.9 & $<\mathrm{DL}$ & 1015.0 & 3.3 & 3.8 & $<\mathrm{DL}$ & 11.0 & 32.2 & 29.4 & $<\mathrm{DL}$ & 120.0 \\
\hline$p-p ' D D D$ & 61.3 & 31.1 & 18.0 & 150.0 & 0.4 & 1.4 & $<\mathrm{DL}$ & 4.9 & 5.5 & 5.4 & $<\mathrm{DL}$ & 17.0 \\
\hline p-p' DDT & 2.0 & 4.9 & $<\mathrm{DL}$ & 18.0 & $<\mathrm{DL}$ & $<\mathrm{DL}$ & $<\mathrm{DL}$ & $<\mathrm{DL}$ & $<\mathrm{DL}$ & $<\mathrm{DL}$ & $<\mathrm{DL}$ & $<\mathrm{DL}$ \\
\hline SumDDTs & 336.6 & 265.7 & 63.0 & 1183.0 & 3.7 & 3.7 & $<\mathrm{DL}$ & 11.0 & 37.7 & 34.3 & $<\mathrm{DL}$ & 137.0 \\
\hline CB52 & - & - & $<\mathrm{DL}$ & $<\mathrm{DL}$ & 0.6 & 2.0 & $<\mathrm{DL}$ & 7.0 & - & - & $<\mathrm{DL}$ & $<\mathrm{DL}$ \\
\hline CB153 & 3.4 & 3.2 & $<\mathrm{DL}$ & 7.0 & 1.0 & 2.3 & $<\mathrm{DL}$ & 6.8 & 3.1 & 4.1 & $<\mathrm{DL}$ & 11.0 \\
\hline CB138 & 1.2 & 2.5 & $<\mathrm{DL}$ & 7.0 & 0.8 & 2.8 & $<\mathrm{DL}$ & 9.7 & 0.5 & 1.8 & $<\mathrm{DL}$ & 7.8 \\
\hline Sum7PCBs & 4.6 & 5.0 & $<\mathrm{DL}$ & 14.0 & 2.4 & 5.6 & $<\mathrm{DL}$ & 16.5 & 3.7 & 5.3 & $<\mathrm{DL}$ & 18.8 \\
\hline
\end{tabular}

SD, Standard deviation; DL, detection limit.

Table 5. Epidemiological parameters of the invasive species A. crassus of eels sampled in three Mediterranean lagoons (Canet, Salses and Bages). Percentage of silver eels having a swimblader degenerative index $(\mathrm{SDI})>4$, indicating sever damage (Lefebvre et al. 2002). Prev: prevalence; Lt: total length.

\begin{tabular}{|c|c|c|c|c|c|c|c|c|c|c|c|c|}
\hline & $\mathrm{N}$ & $\begin{array}{l}\text { Mean } \\
\text { Lt (min-max) }\end{array}$ & $\begin{array}{l}\text { Prev } \\
(\%)\end{array}$ & $\begin{array}{l}\text { Mean } \\
\text { Intensity }\end{array}$ & SD & Min. & Max. & $\begin{array}{l}\text { Mean } \\
\text { SDI }\end{array}$ & SD & Min. & Max. & $\begin{array}{l}\text { SDI > } \\
4(\%)\end{array}$ \\
\hline Canet07 & 24 & $38.9(33.3-46.1)$ & 41.7 & 4.0 & 2.2 & 1 & 7 & 3.8 & 0.8 & 2 & 5 & 63 \\
\hline Canet08 & 28 & $35.9(32.7-43.5)$ & 14.3 & 1.3 & 0.5 & 1 & 2 & 2.8 & 1.6 & 0 & 6 & 29 \\
\hline Salses & 53 & $35.5(29.5-40.3)$ & 3.8 & 7.5 & 7.8 & 2 & 13 & 1.2 & 1.4 & 0 & 6 & 8 \\
\hline Bages07 & 30 & $38.8(34.4-43)$ & 6.7 & 1.0 & 0.0 & 1 & 1 & 1.1 & 0.8 & 0 & 3 & 0 \\
\hline Bages08 & 80 & $38.8(34.5-46.5)$ & 3.8 & 4.7 & 4.7 & 1 & 10 & 1.4 & 1.8 & 0 & 6 & 19 \\
\hline Berre & 6 & $35.0(34.1-35.8)$ & 33.3 & 2.5 & 0.7 & 2 & 3 & 3.7 & 1.5 & 2 & 6 & 67 \\
\hline
\end{tabular}

SD, Standard deviation.

\section{EVEX testing}

Eel Virus European X (EVEX) testing was performed by the French Agency for Food, Environmental and Occupational Health \& Safety (ANSES). A total of 6, 12, 12 and 3 eels were analysed in Canet, Salses, Bages lagoons and La Berre River, respectively. For each eel, a pool of organs including kidney, spleen, brain and heart was analysed. The technique involved culturing each pool of organs on different fish cell lines and identifying EVEX by seroneutralisation using a rabbit anti-EVEX serum according to the protocol set-up by Castric \& Chastel (1980).

\section{Data analysis}

Statistical analyses were performed with Statistica 10 software. Because the data were not normally distributed and showed large variance, nonparametric tests were used: Mann-Whitney $U$-test and Kruskal-Wallis $(\mathrm{KW})$ test followed by a Dunn's test (to determine differences between groups). To increase the number of eels studied from Canet and Bages lagoons, we pooled the two sampling periods (2007 and 2008) when no significant difference was found between the two sampling years. The difference of lipid contents between sites was analysed with an ANCOVA with length as the covariate. Results were expressed as mean \pm SD (standard deviation). Relationships between contaminant (biological and chemical) levels and biomorphological data were determined with the Spearman's rank correlation coefficient $r$. The Fisher's test was used to determine differences in prevalence between sites. All results were considered as statistically significant when $P<0.05$.

\section{Results}

\section{Morphometrics}

A total of 222 male silver eels of $29.1-46.5 \mathrm{~cm}$ in total length were collected during their migration period back to the Sargasso Sea. Their total length, weight, Pankhurst's ocular index (OI), age (in year), Fulton condition index (K), lipid content in muscle, hepatosomatic index (LI) and spleen index (SI) are presented in Table 2.

First, we looked at interannual variation in morphometric parameters for the two sites where eels were collected over a period of 2 years: Bages and 
Canet lagoons. Silver eels captured in Bages lagoon showed no significant difference between 2007 and 2008 in length, age, condition factor and lipid level (KW test, $P>0.05$ ). Therefore, we grouped the Bages 2007 and 2008 data when comparing with the other studied sites. Conversely, silver eels captured in Canet in 2007 differed significantly with those captured in 2008 for Lt, age, $\mathrm{K}$ and lipids level (KW test, $P<0.05$ ). Eels collected in 2007 were longer, older and with higher level of fat compared with those collected in 2008 (Dunn's tests, $P<0.05)$. However, condition factor $\mathrm{K}$ was greater in 2008 (Dunn's test, $P<0.05$ ). These differences could be due to particular environmental conditions encountered in this confined lagoon during summer 2008, including an important eutrophication event caused by the closure of the opening to the sea. These two samples, Canet 2007 and Canet 2008, were therefore kept separate for the remainder of the analyses. Bages eels were longer than the eels coming from Canet in 2008, Salses and La Berre (KW test, $P<0.05$; Dunn's test, $P<0.05)$. Age was correlated with Lt in Canet $(n=52, \quad r=0.44, \quad P<0.05)$ and Bages $(n=107, r=0.26, P<0.05)$ lagoons, but not in Salses or La Berre $(\mathrm{P}<0.05)$. Salses eels were significantly older than those from other sites (KW test, $P<0.05$; Dunn's test, $\mathrm{P}<0.05)$. Sampling location had no significant effect on condition factor except for the eels captured in Canet lagoon in 2008 that showed higher condition factor compared with eels collected from Salses (KW test, $P<0.05$; Dunn's test $P<0.05)$. Fat levels in eels were not significantly different between sites except for eels collected in Canet lagoon in 2008, which showed the lowest levels, significantly lower than those for eels coming from Bages lagoon (ANCOVA, $P<0.05$ ). In our study, lipid content was not correlated with $\mathrm{K}(n=50, r=0.14$. $P>0.05)$ but was correlated with Lt $(n=50$, $r=0.51, P<0.05)$. The hepatosomatic index of eels collected in Canet was significantly higher than that of eels from the three other sites (KW test, $P<0.05$; Dunn's test, $P<0.05$ ). Eels collected in La Berre showed the lowest hepatosomatic indices, significantly lower than those from Canet and Salses (KW test, $P<0.05$; Dunn's test, $P<0.05)$. Eels collected from La Berre and Canet had higher spleen indices compared with the specimens collected in Bages and Salses lagoons (KW test, $P<0.05$; Dunn's test, $P<0.05)$.

\section{Contamination by heavy metals, PCBs and OCs}

The concentrations of heavy metals in liver and muscle are reported in Table 3. Detectable concentrations of heavy metals were found in all individuals. $\mathrm{Cu}$, $\mathrm{Cd}$ and $\mathrm{Zn}$ concentrations were significantly higher in the liver than in muscle ( $U$-test, $P<0.01)$ except for $\mathrm{Cu}$ concentrations of the specimens from $\mathrm{La}$ Berre where no significant difference was found between the two tissues ( $U$-test, $P>0.05$ ).

When comparing concentrations of heavy metals in muscle, we found differences between sites for $\mathrm{Cu}$ and $\mathrm{Cd}(\mathrm{KW}$ tests, $P<0.01)$ but not for $\mathrm{Zn}(\mathrm{KW}$ test, $P>0.05) . \mathrm{Cu}$ and $\mathrm{Cd}$ concentrations were higher in eels captured in La Berre River compared with those captured in Salses lagoon (Dunn's tests, $P<0.01) . \mathrm{Cu}$ concentrations in eels were also higher in eels from Canet lagoon compared with Salses lagoon (Dunn's test, $P<0.01$ ), and Cd concentrations were higher in eels from Bages lagoon compared with those from Salses (Dunn's test, $P<0.01$ ).

The concentrations of heavy metals in liver were different between sites for $\mathrm{Cu}, \mathrm{Cd}$ and $\mathrm{Zn}$ (KW tests, $P<0.05)$. Eels collected in Bages lagoon had higher concentrations of $\mathrm{Cu}$ compared with the eels coming from Canet lagoon (Dunn's test, $P<0.05$ ). Eels from Bages lagoon and La Berre River had higher concentrations of $\mathrm{Cd}$ compared with the ones from Salses lagoon (Dunn's test, $P<0.05$ ). Eels from La Berre also had higher concentrations of Cd compared with those from Canet lagoon (Dunn's test, $P<0.01$ ). Finally, we found that eels collected in La Berre had higher concentrations of $\mathrm{Zn}$ compared with the eels collected in Bages and Canet lagoons (Dunn's test, $P<0.01)$. However, eels from Salses lagoon were significantly more contaminated with $\mathrm{Zn}$ than the eels from Bages lagoon (Dunn's test, $P<0.05$ ).

Variation in metal concentration in muscle tissue across individuals within each site was very high (up to a factor 67 for $\mathrm{Cu}, 57$ for $\mathrm{Cd}$ and 25 for $\mathrm{Zn}$ ) and in liver tissue (up to a factor 71 for $\mathrm{Cu}, 7$ for $\mathrm{Cd}$ and 4 for $\mathrm{Zn}$ ).

No significant relationships were found between metal concentrations and $\mathrm{K}$. $\mathrm{Cu}$ concentration in liver was significantly correlated with lipid content $(n=31, r=0.38, P<0.05)$ and length $(n=65$, $r=0.31, P<0.05)$. Concentrations of $\mathrm{Cu}, \mathrm{Cd}$ in liver tissue and $\mathrm{Zn}$ in muscle tissue were negatively correlated with the hepatosomatic index (Cu-LI: $n=65, \quad r=-0.45, \quad P<0.05 ; \quad$ Cd-LI: $n=65$, $r=-0.53, \quad P<0.05 ; \quad$ Zn-LI: $n=58, \quad r=-0.28$, $P<0.05$ ). For the spleen index, a significant negative correlation was found with $\mathrm{Cu}$ concentrations in liver $(n=65, r=-0.27, P<0.05)$. No correlation between metal concentration and age was found $(P>0.05)$.

The mean concentrations of SumDDTs and Sum7PCBs in eel muscles from Canet and Bages lagoons were not significantly different between 2007 and 2008 ( $U$-test, $P>0.05$ ). The samples from both years were therefore grouped to enlarge the sample number in each site. PCBs and OCs concen- 
tration levels are given in Table 4. For OCs, only DDTs were detected. DDTs were the most abundant pollutants followed by PCBs. DDT compounds were detected in $88 \%$ of the eels and PCBs in $40 \%$ of the eels. All the eels captured in Canet lagoon had higher concentrations of SumDDTs than those found in eels from the other lagoons (KW test, $P<0.05$; Dunn's test $P<0.05$ ). Eels from Salses lagoon were less contaminated, with a mean SumDDTs concentration significantly lower compared with that observed in eels from Bages lagoon (Dunn's test, $P<0.05$ ). The main component detected was p,p'-DDE, which contributed more than $70 \%$ of the SumDDTs on average per eel, and had concentrations ranging from under the detection limit to $1015 \mathrm{ng} \cdot \mathrm{g}^{-1} \mathrm{ww}$. The compound p-p'DDT was only found in eels from Canet and La Berre (6 and $19 \mathrm{ng} \cdot \mathrm{g}^{-1}$ ww muscle; $N=2$ ) sites. p,p'DDE and p,p'-DDD concentrations in eels from Canet lagoon were significantly higher compared with those in eels from the other two lagoons (KW test, $P<0.05$, Dunn's test, $P<0.05$ ).

Only three PCBs congeners were detected: CB52, CB153 and CB138. CB 153 was predominant in all sites (41-92\% average contribution to the Sum7PCBs), followed by the congeners 138 (8-29\%) and 52 (29\%, only detected in Salses lagoon). The concentrations of the seven indicator PCBs ranged from under detection limit to $18.8 \mathrm{ng} \cdot \mathrm{g}^{-1} \mathrm{ww}$. The mean Sum7PCBs concentrations were not significantly different between sites (KW test, $P>0.05$ ).

Pooling the data from all the sites, Sum7PCBs and SumDDTs were positively correlated $(n=50$, $r=0.52, P<0.05)$. Sum7PCBs was correlated with age $(n=14, r=0.61, P<0.05)$ in Canet eels, while SumDDTs was correlated with length $(n=12$, $r=0.67, P<0.05)$ in Salses eels and with LI $(n=5$, $r=-0.90, P<0.05)$ in Canet eels. No significant correlations were found between POPs concentrations and lipids, condition factor or spleen index $(P>0.05)$.

\section{Anguillicolosis}

The epidemiological results for A. crassus are presented in Table 5 . The prevalence ranged from $4 \%$ (in Salses lagoon) to $42 \%$ (in Canet lagoon, 2007). We first compared the interannual variation (2007/2008) for Canet and Bages lagoons. The prevalence (Fisher's test, $P<0.05)$ and the mean intensity ( $U$-test, $P<0.05)$ were significantly higher in eels collected in Canet in 2007 compared with the eels collected in 2008. However, we found no differences between 2007 and 2008 for Bages lagoon (Fisher's test, $P>0.05$ and $U$-test, $P>0.05)$. Although prevalence was highest in Canet lagoon and La Berre River, only the eels collected from Canet lagoon in 2007 had significantly higher prevalence than eels from Bages and Salses lagoons (Fisher's test, $P>0.05$ ). Mean inten- sity ranged from $1.0 \pm 0.0$ (Bages) to $7.5 \pm 7.8$ (Salses). A. crassus mean intensity was not different between sites (KW test, $P>0.05$ ). The eels captured in Canet (2007 and 2008) and La Berre had a higher SDI compared with the eels sampled in Bages (2008) and Salses (KW test, $P<0.05$, Dunn's test, $P<0.05)$. The percentage of eels having a severely damaged swim bladder (SDI $\geq 4$ ) was higher in Canet (63\% in 2007 and 29\% in 2008) and La Berre (67\%) compared with Bages (0\% in 2007 and $19 \%$ in 2008) and Salses $(8 \%)$. No correlations were found between A. crassus parameters (intensity and SDI) with condition factor, lipid content, length or age $(P>0.05)$. A. crassus intensity (AC) and SDI were positively correlated with the levels of SumDDTs and $\mathrm{Cu}$ in muscle (AC-SumDDTs: $n=50, r=0.29, P<0.05$; SDI-SumDDTs: $n=50, r=0.44, P<0.05$; AC-Cu: $n=60 ; \quad r=0.32, \quad P<0.05 ; \quad$ SDI-Cu: $n=60$, $r=0.39, P<0.05)$. A positive correlation was found between SDI and SI $(n=165, r=0.41, P<0.05)$ and $\operatorname{LI}(n=165, r=0.31, P<0.05)$.

\section{Virus detection}

The EVEX was detected only in Salses lagoon where two specimens were infected out of the 12 examined $(17 \%)$.

\section{Discussion}

\section{Chemical contamination levels}

Each site showed a different 'cocktail' of contaminants with no simple patterns of pollution. Lagoons are known to be characterised by a great variability of environmental conditions and by strong seasonal variations in physical factors such as salinity and temperature (Viaroli et al. 2007), but also in other physical factors like wind-induced water currents, that could potentially modify pollutants' bioavailability. For example, in the studied region, the strength and direction of the wind extensively influenced the water and the sediment dynamics, which could play an important role in resuspending particulate contaminants (Zhang et al. 2012).

Some contaminants displayed comparable or lower values when compared with other Mediterranean sites reported by other studies (Table 6). Zn concentrations in muscles and liver found in the studied sites were comparable to those from the other Mediterranean sites. Gediz River (Turkey), where Zn concentrations are surprisingly very low, is the only exception. Mean levels of PCBs (sum of the seven indicators) measured in our study $\left(2-4.6 \mathrm{ng} \cdot \mathrm{g}^{-1}\right.$ wet muscle) were generally lower than those reported for eels from other Mediterranean regions, where concen- 
Silver eels quality in Mediterranean habitats

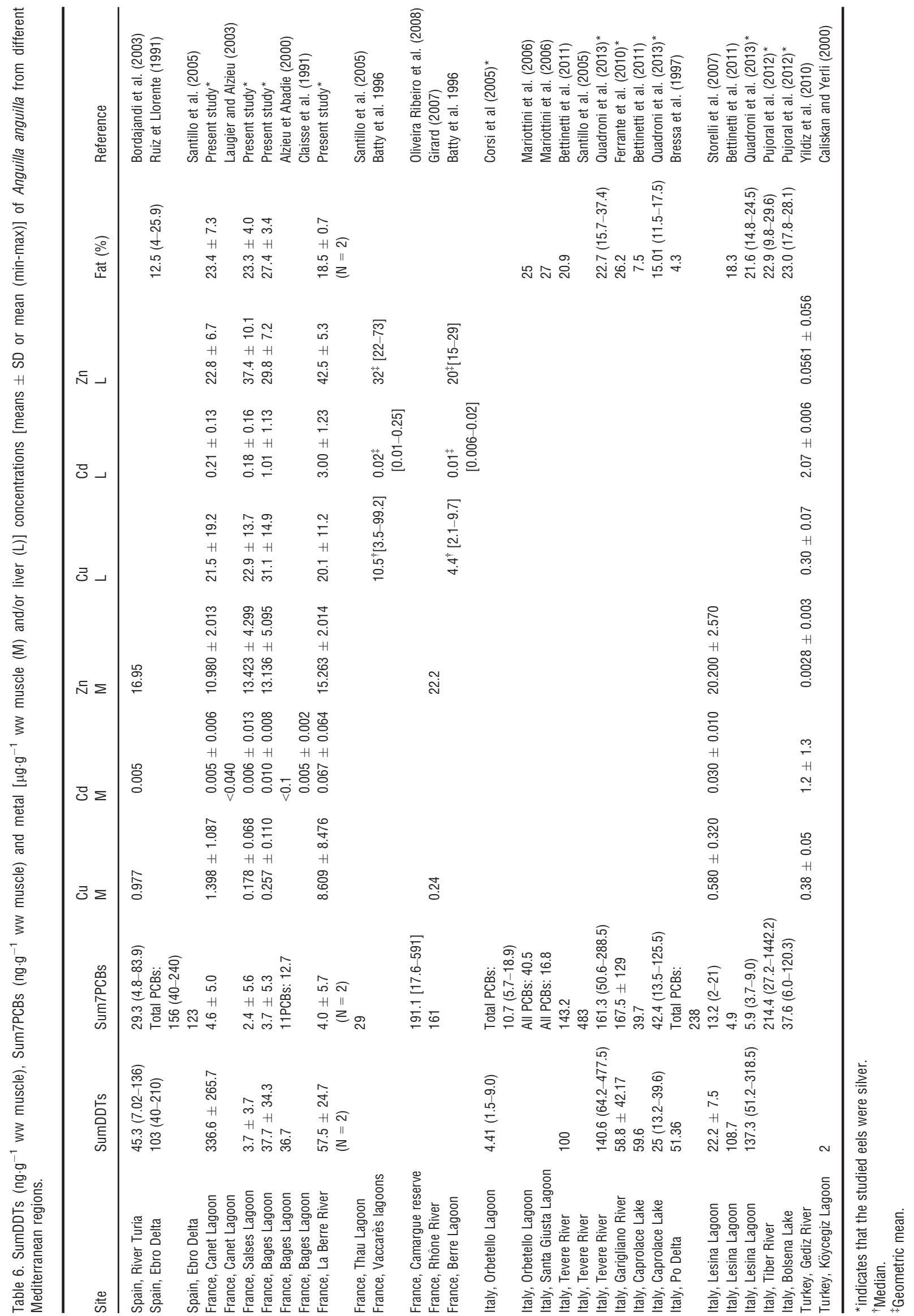


trations were 10-100 times higher (Bordajandi et al. 2003; Santillo et al. 2005; Girard 2007; Oliveira Ribeiro et al. 2008; Bettinetti et al. 2011; Ferrante et al. 2010). Only eels from Lesina lagoon in Italy showed similar concentrations (Bettinetti et al. 2011; Quadroni et al. 2013). The congeners that contributed most to total PCBs were CB 153 and CB138 in all of our studied sites. This result is in agreement with data reported for eels from other studies in the Mediterranean region (Bordajandi et al. 2003; Mariottini et al. 2006; Storelli et al. 2007; Oliveira Ribeiro et al. 2008; Ferrante et al. 2010; Macgregor et al. 2010) and from the study of Flanders (Belpaire et al. 2010) and corresponds to commercial PCBs mixtures (Aroclor 1254 and 1260) used in most European countries (Ferrante et al. 2010). The concentrations of the sum7PCBs were among the lowest compared with other European countries (Belpaire et al. 2011).

\section{High levels of DDTs and $\mathrm{Cu}$ in Canet lagoon}

Eels collected in Canet lagoon showed the highest level of contamination with DDTs and also high $\mathrm{Cu}$ concentrations compared with the other sites studied here. The particularly high DDTs values found in eels from Canet lagoon (10 times higher compared with the other studied sites) were comparable to those reported from Ebro delta in Spain (Ruiz \& Llorente 1991), Tevere River and Lesina lagoon in Italy (Bettinetti et al. 2011), sites considerably affected by the outputs of agricultural activities. As DDT is metabolised to DDE, the ratio DDE/DDT is used to determine whether DDT was released recently into the environment. The samples in Canet lagoon presented a ratio DDE/DDT $>1$, corresponding to the long period since DDT was banned in France (1972). As there were no previous surveys of DDT contamination in eels from Canet lagoon, it was not possible to examine temporal trends. However, no decrease was observed in Bages lagoon after a 10-year period (Alzieu \& Abadie 2000).

High concentrations of $\mathrm{Cu}$ in eel muscles from Canet lagoon were comparable to those found in other Mediterranean sites such as River Turia (Bordajandi et al. 2003) and Lesina lagoon (Storelli et al. 2007). These high levels of contamination (DDTs and $\mathrm{Cu}$ ) might be explained by the peculiar physical characteristics of this lagoon. The shallow depth, low surface area and limited connection with the sea (Bernat et al. 1984), similar to the Lesina lagoon, may contribute to resuspension of the pollutants accumulated in sediment during strong wind events. In addition, the greater agricultural activity (fruit cultures and viticulture) around the lagoon of Canet compared with the other sites might also explain the high values observed. The confined situation of the lagoon could also have led to high concentrations of DDT applied for pest and/or mosquito control.
Higher concentration of $C d$ in Bages lagoon

Concentrations of $\mathrm{Cd}$ found in the liver of eels from Bages lagoon were four times higher than those in eels collected in the other two lagoons. This could be explained by the historical contamination in this lagoon in the 1980s-1990s, from a colour maker factory releasing $\mathrm{Cd}$ residues in the environment. $\mathrm{Cd}$ stored in sediments was regularly resuspended, following meteorological events, bioturbation or public works. In comparison, concentrations in eels from Vaccarès and Berre lagoons were 10 times lower (Batty et al. 1996). However, Cd concentrations found in eel muscles from Bages lagoon were low and similar to those reported in the other studied lagoons and in the River Turia (Bordajandi et al. 2003). These results highlight the importance of searching for this metal in different tissues to give a complete overview of the contamination.

High plurimetallic contamination in La Berre River Eels collected in La Berre River showed particularly high concentrations of metallic pollutants compared with lagoons. The mean concentration of $\mathrm{Cu}$ found in muscles of eels from La Berre was at least 20 times higher than those reported in eel muscles collected from Salses and Bages lagoons, River Rhône (Girard 2007) and Gediz River (Yildiz et al. 2010). In addition, even if the mean concentration of $\mathrm{Cu}$ in the liver of eels collected in La Berre was comparable to the others studied sites, it was nonetheless twice as high as those measured in eels collected in Vaccarès and Berre lagoons (Batty et al. 1996). The Cd concentrations in eel muscle were two times higher compared with the concentrations found in the Lesina lagoon (Storelli et al. 2007) and 10 times higher compared with the studied lagoons and River Turia (Bordajandi et al. 2003). These levels were low compared with the particularly high levels found in Gediz River (about 200 times higher) (Yildiz et al. 2010). As there are no industries on this river, this pattern may be explained by the physico-chemical conditions peculiar to rivers compared with lagoons. Indeed, salinity and temperature variations are known to influence the uptake and metabolism of heavy metals (Gony et al. 1988; Tabouret et al. 2011). The atmospheric deposition of pollutants could also explain this pattern (Radakovitch et al. 2008). This highlights the importance to consider both brackish and freshwater habitats when monitoring eel quality in a catchment.

\section{Virus and parasite infection levels}

In our study, EVEX was only detected in Salses lagoon and with a low prevalence (17\%). Although it was previously detected in glass eels entering the Vaccarès lagoon (Girard 2005), this is the first time EVEX has 
been reported from silver eels in the Mediterranean, and there were no data available on EVEX epidemiology to compare with our results. Previous reports are from wild and farmed European eels from along the European Atlantic coast, from Morocco to Russia, and also in New Zealand from Anguilla dieffenbachii (van Ginneken et al. 2004; Haenen et al. 2010).

Anguillicoloides crassus has been extensively studied and recorded in almost all the European countries. In the present study, we found relatively low prevalence (ranging from $4 \%$ to $42 \%$ ) depending on the site. Fazio et al. (2008) recorded higher prevalence in French Mediterranean lagoons, i.e., 67\% in Salses lagoon and up to $94 \%$ in Mauguio lagoon in July 2004. The sampling season may explain this difference with a maximal infection in summer when oxygen availability is low (Lefebvre et al. 2002; Fazio et al. 2008). It is also possible that environmental conditions are not optimal for the life cycle of the parasite to complete in these sites (Fazio et al. 2008). Infections in the studied lagoons seemed lower than those in the majority of the Atlantic side silver eel subpopulations (EELIAD project, unpublished data). Finally, the salinity might also play an important role in the infestation success (Kirk et al. 2000; Lefebvre et al. 2003) and explain the low prevalence we found in marine lagoons (Salses and Bages) compared with the less saline ones such as Vaccarès and Mauguio. This pattern has been shown in Mediterranean habitats in Algeria (Djebbari et al. 2009).

\section{Contamination effect on eel condition}

Surprisingly, K was not correlated with fat contents as in other lagoons (Quadroni et al. 2013). K may not be the most appropriate variable to measure individual energetic state in this study. No correlation was found between $\mathrm{K}$ and the contaminant concentrations (metals and POPs). This finding could result from the complexity of the multicontamination patterns in each local stock and the fact that we considered each contaminant separately. Using a multimetal bioaccumulation index, Maes et al. (2005) found a negative correlation between metal load and condition (K and LI). The negative correlation between the hepatosomatic index and the metal's concentration, $\mathrm{Cu}$ and $\mathrm{Cd}$ (in liver) and $\mathrm{Zn}$ (in muscle), found in this study is in agreement with published data for $\mathrm{Cd}$ (Jovanović et al. 2011). We also found significant correlations between $\mathrm{Cu}$ concentrations in liver and the length of the eels. A significant correlation between length and $\mathrm{Cu}$ had previously been found in the Vaccarès lagoon (Batty et al. 1996). Finally, the positive correlation we found between Sum7PCBs and age in eels from Canet suggested that older specimens have accumulated more PCBs. Our study showed that DDT and $\mathrm{Cu}$ in muscle levels were positively correlated with $A$. crassus intensity and swim bladder damage. This result is in accordance with Quadroni et al.'s (2013) results for DDT. Pollutants can weaken the immune system and increase the eel's sensitivity to parasite infections (Robinet \& Feunteun 2002; Sures \& Knopf 2004). The observed relationship between the severity of the swim bladder damage and the spleen mass suggested an adaptive response of the host to the increased demand for red cells and splenic immune cells induced by the parasite via swim bladder wall damage and blood feeding activity (Lefebvre et al. 2004).

\section{Quality of the spawners and reproductive potential}

Eels from other Mediterranean lagoons (Table 6) showed muscle fat contents similar to those reported in the three studied lagoons: Canet, Salses and Bages. Eels from freshwater habitats (La Berre River and the other freshwater habitats, Table 6) show lower fat percentages, which is likely to be related to the low productivity of these environments. This highlights the potential importance of brackish water systems as eel habitats (Marohn et al. 2013). Spawning success of the eels depends on the fat accumulation during their continental phase (Boëtius \& Boëtius 1980). Silver eels are thought to cease feeding and entirely rely on lipid reserves for migration, gonad maturation and mating activities. Research on eel reproduction has been mostly focused on females, and information on males is very scarce. If we consider $13 \%$ as the minimum required for migration (van den Thillart et al. 2004; based on females data), only one specimen (over the 50 analysed in our study) had $<13 \%$ fat content (coming both from Canet lagoon in 2008). Based on time series data on lipid contents from yellow eels, Belpaire et al. (2009) suggested that males from the north Atlantic coasts may not have sufficient lipid contents to reach the spawning ground. Our result supports the idea that southern countries may be important contributors to the spawning stock (Kettle et al. 2008). Mediterranean lagoons therefore may be important reservoirs of male eels not only in terms of number (Mallawa 1987; Amilhat et al. 2008) but also in terms of males having sufficient lipid reserves for migration. But lipid quantity is not the only important criterion to determine the success of migration. Quality is a crucial point as bioaccumulated contaminants will be released during migration, when fat is mobilised for metabolic activity, and may impair the reproduction (migration and/or gamete production) of the female eel (van Ginneken et al. 2009).

An Eel Quality Index (EQI) is being developed by the ICES Working Group on Eels with the aim of 
being able to include eel quality in future quantitative assessment of the spawner biomass (ICES 2012). EQI is calculated for individual eels and is currently based on quality classes determined for each contaminant and pathogen although it should be noted that these classes are set statistically from field samples of yellow eel from an extensive 12-year study of contaminant monitoring in eel in Flanders (2946 eels from 365 sites) and have not been related to reproductive success. Such a system has been set for other species such as sole and whiting but not yet for eel. For each pollutant, a reference value was defined as the fifth percentile value of the means of all sites. Then, four quality classes were developed as a measure of deviation from the reference value: class 1 corresponding to the 'not impacted' eels; class 2, 'slightly impacted'; class 3, 'impacted'; and class 4, 'strongly impacted'. This approach was extended to consider pathogens (ICES 2012), and Table 7 reports the boundary values for the pathogens and contaminants analysed in our study. As we found a positive correlation between SDI and the intensity of the parasite A. crassus, the limit was set up at SDI $\geq 4$, accounting not only for the parasite load but also for past infestations (Lefebvre et al. 2002; Palstra et al. 2007).

The distribution of the quality classes (Fig. 2) differs in the four water bodies, except for PCBs and $\mathrm{Zn}$ with $100 \%$ of the studied eels unimpacted. Canet lagoon and La Berre River eels are the most impacted for DDTs, $\mathrm{Cu}$ and $\mathrm{Cd}$ contaminations and A. crassus infestation. Bages eels are particularly impacted by $\mathrm{Cd}$, and EVEX has been only recorded in Salses lagoon. Because of the low number $(\leq 6)$ of eels studied for La Berre and Canet in 2008, we should be cautious about the interpretation of the results for those sites. These data show that a non-negligible proportion of the male silver eels in the studied catchments are of low quality and low reproductive potential. However, this considers each contaminant and pathogen separately and does not consider the synergetic effects caused by these stressors. Applying the total
Table 7. Boundary values of the quality classes for parasite Anguillicoloides crassus, virus EVEX, POPs (Sum 7 PCBs ans Sum DDTs) and 3 metals $(\mathrm{Cd}, \mathrm{Cu}$ and $\mathrm{Zn})$ and the Eel Quality Index (EQI). PCBs, DDTs and Cd are expressed in $\mathrm{ng} \cdot \mathrm{g}^{-1}$ ww muscle. Cu and $\mathrm{Zn}$ in $\mu \mathrm{g} \cdot \mathrm{g}^{-1}$ ww muscle.

\begin{tabular}{lllll}
\hline & Not impacted & $\begin{array}{l}\text { Slightly } \\
\text { impacted }\end{array}$ & Impacted & $\begin{array}{l}\text { Strongly } \\
\text { impacted }\end{array}$ \\
\hline $\begin{array}{l}\text { Quality Classes } \\
\text { Disease/contaminants }\end{array}$ & 1 & 2 & 3 & 4 \\
SDI & 0 & $1-2$ & 3 & $\geq 4$ \\
Evex virus & Not present & & & Present \\
Sum 7 PCBs & $<73$ & $73-<183$ & $183-<460$ & $\geq 460$ \\
Sum DDTs & $<40$ & $40-<101$ & $101-<254$ & $\geq 254$ \\
Cd & $<5$ & $5-<12.6$ & $12.6-<31.7$ & $\geq 31.7$ \\
Cu & $<0.6$ & $0.6-<1.6$ & $1.6-<4$ & $\geq 4$ \\
Zn & $<35$ & $35-<88$ & $88-<222$ & $\geq 222$ \\
EQI & $<1.50$ & $1.51-2.50$ & $2.51-3.50$ & $3.51-4$ \\
\hline
\end{tabular}

SDI, Swim bladder Degenerative Index.

$\mathrm{EQI}_{\text {tot }}$ index (ICES 2012), if we consider the 29 specimens for which A. crassus, PCBs, DDTs and Cd data were available simultaneously, no single strongly impacted eel was recorded for the three lagoons. This result differs from analysis where contaminants are considered separately and may be due to the low sample size. More than $50 \%$ of Salses eels were 'not impacted', whereas no eels in this category were recorded in Bages and Canet lagoons. Most of the eels, 60 and 80\%, respectively, in Bages and Canet lagoons, were 'slightly impacted', and the remaining, 40 and 20\%, respectively, were 'impacted'. Eel quality status is in general better in Salses compared with the other studied sites. The particular physical characteristics of this lagoon can explain this pattern. Salses has the highest area, depth, mean salinity and also the smaller river basin area. Also, it has three openings to the sea and two important seepages, which allow a good renewal of the water and sediments. Industrial and urban pressure is also less compared with Bages and Canet lagoons. In terms of management effort to increase the number of good-quality spawners, it would be beneficial to protect less impacted lagoons

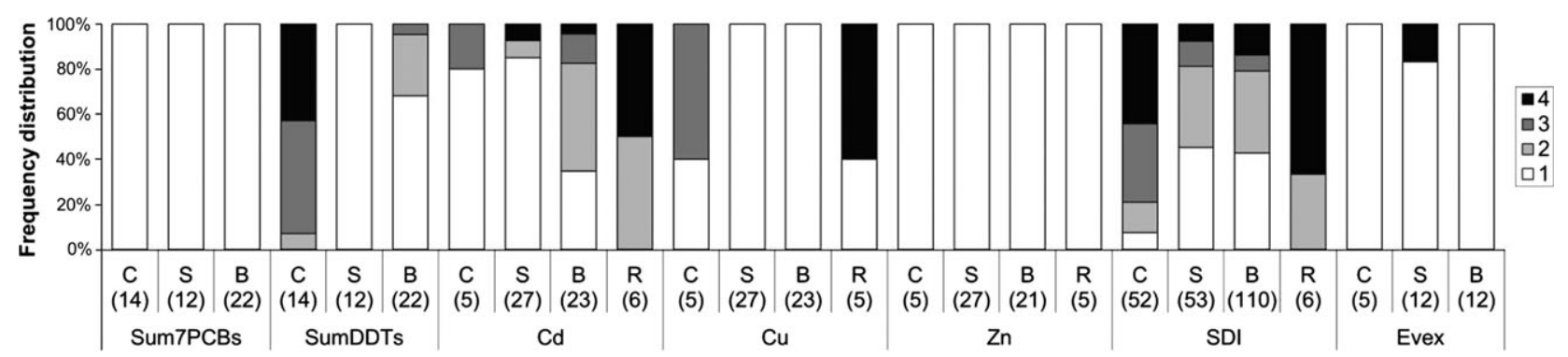

Fig. 2. Eel Quality Index (EQI) distribution in Canet (C), Salses (S) and Bages (B) lagoons and La Berre River (R). The number under the site code refers to the number of samples for each site. Class 1 corresponds to the not impacted eels; class 2, the slightly impacted; class 3 , the impacted; and class 4, the strongly impacted. Five contaminants: Sum7PCBs, SumDDTs, Cadmium, Copper and Zinc, and two pathogens: parasite Anguillicoloides crassus (AC) and virus EVEX are considered. 
such as Salses and, on the most polluted sites, to limit additional contamination as well as to investigate ways to reduce anthropogenic pressure.

\section{Conclusions}

In this study, we showed that closely located habitats in the Mediterranean region exhibit different patterns of eel contamination and diseases. Canet eels show a high level of parasitism and a high contamination with DDTs, demonstrating the persistence of DDT, which has been banned since 1972. At Bages lagoon, eels were moderately parasitised but exhibited significant $\mathrm{Cd}$ contamination explained by historical releases from a colour maker factory. Salses eels exhibited the lowest contamination levels and moderate level of parasitism, but were the only eels in which EVEX was detected. Although it is difficult to generalise about the health of eels in La Berre River because of the low number of samples, those sampled were particularly contaminated and parasitised. Environmental parameters such as surface area of the water body, depth, connections with the sea, size of the river basin and anthropogenic stressors are important factors in determining eel quality status. This study highlights the importance of considering spawner quality per catchment in eel management plans and conservation measures such as fishing restrictions and/or designating protected areas. The most contaminated eels have potentially reduced chances to migrate and reproduce successfully. Further work on dose-effect experimental studies including antagonistic and/or synergistic effects of contaminations and infections is urgently needed to quantify the impact of multiple stressors on eel migration and reproduction potential. This study supports and contributes to the initiatives of the joint EIFAAC/ICES WGEEL to set up a European Eel Quality Database to collect data on contaminants and diseases over the eel habitat (Belpaire et al. 2011).

\section{Acknowledgement}

The research has been supported by IFREMER and GRISAM. The authors are indebted to the fishermen Didier Peyrille, Alain Cyprien, Pons and Cribeille who provided the silver eels. Thanks also to the local fishing committees for their support and help in arranging meetings with the fishermen, especially Dominique Blanchard. The authors are very grateful to Sylvain Richard, Laurent Ratineau and Hervé Archilla from the ONEMA for eels collected on La Berre River. We thank the reviewers, Russell Poole, Penny Hancock, Leon Meyer, Suzanne Mills and Edouard Jobet for the improvement they made in the manuscript.

\section{References}

Acou, A., Lefebvre, F., Contournet, P., Poizat, G., Panfili, J. \& Crivelli, A.J. 2003. Silvering of female eels (Anguilla anguilla) in two sub-populations of the Rhône Delta. Bulletin Français de la Pêche et de la Pisciculture 368: 55-68.

Acou, A., Boury, P., Laffaille, P., Crivelli, A.J. \& Feunteun, E. 2005. Towards a standardized characterization of the potentially migrating silver European eel (Anguilla anguilla, L.). Archives of Hydrobiology 164: 237-255.

Als, T.D., Hansen, M.M., Maes, G.E., Castonguay, M., Riemann, L., Aarestrup, K., Munk, P., Sparholt, H., Hanel, R. \& Bernatchez, L. 2011. All roads lead to home: panmixia of European eel in the Sargasso Sea. Molecular Ecology 20: 1333-1346.

Alzieu, C. \& Abadie, E. 2000. Contamination de l'étang de Bages-Sigean par les polluants chimiques - Incidence des inondations de novembre 1999. Ifremer report, $31 \mathrm{pp}$.

Amilhat, E., Farrugio, H., Lecomte-Finiger, R., Simon, G. \& Sasal, P. 2008. Silver eel population size and escapement in a Mediterranean lagoon: Bages-Sigean, France. Knowledge and Management of Aquatic Ecosystems 05: 390-391.

Batty, J., Pain, D. \& Caurant, F. 1996. Metal concentration in eels Anguilla anguilla from the Camargue region of France. Biological Conservation 76: 17-23.

Belpaire, C.G.J., Goemans, G., Geeraerts, C., Quataert, P., Parmentier, K., Hagel, P. \& De Boer, J. 2009. Decreasing eel stocks: survival of the fattest? Ecology of Freshwater Fish 18: 197-214.

Belpaire, C., Geeraerts, C., Roosens, L., Neels, H. \& Covaci, A. 2010. What can we learn from monitoring PCBs in the European eel? A Belgian experience. Environment International 37: 354-364.

Belpaire, C., Geeraerts, C., Evans, D., Ciccotti, E. \& Poole, R. 2011. The European eel quality database: towards a panEuropean monitoring of eel quality. Environmental Monitoring and Assessment 183: 273-284.

Bernat, M., Cauwet, G., Chassefiere, B., Faguet, D., Gadel, F., Monaco, A., Ouakad, M. \& Thommeret, Y. 1984. Behaviour of metallic and radioactive elements in lagoonal sediments: the example of the Canet-St Nazaire Pond (Mediterranean coast). Estuarine, Coastal and Shelf Science 18: 557-570.

Bettinetti, R.B.R., Galassi, S., Quadroni, S., Volta, P., Capoccioni, F., Ciccotti, E. \& De Leo, G.A. 2011. Use of Anguilla anguilla for Biomonitoring Persistent Organic Pollutants (POPs) in Brackish and Riverine Waters in Central and Southern Italy. Water Air and Soil Pollution 217: 321-331.

Boëtius, I. \& Boëtius, J. 1980. Experimental maturation of female silver eels, Anguilla anguilla. Estimates of fecundity and energy reserves for migration and spawning. Dana 1: $1-28$.

Bordajandi, L.R., Gómez, A., Fernández, M.A., Abad, E., Rivera, J. \& González, M.J. 2003. Study on PCBs, PCDD/ Fs, organochlorine pesticides, heavy metals and arsenic content in freshwater fish species from the River Turia (Spain). Chemosphere 53: 163-171.

Bressa, G., Sisti, E. \& Cima, F. 1997. PCBs and organochlorinated pesticides in eel (Anguilla anguilla L.) from the Po Delta. Marine Chemistry 58: 261-266. 
Buscail, R., Vouvé, F., Lecomte-Finiger, R., Lenfant, P., Pastor, J., Abdullah, M. \& Certain, R. 2009. Entre terre et mer: la lagune de Salses-Leucate, un "lac marin". In: Quæ, ed. Le Golf du Lion. Versailles, France: Un observatoire de l'environnement en Méditerranée, pp. 167-182.

Bush, A.O., Lafferty, K.D., Lotz, J.M. \& Shostak, A.W. 1997. Parasitology meets ecology on its own terms: Margolis et al. revisited. Journal of Parasitology 83: 575-583.

Caliskan, M. \& Yerli, S.V. 2000. Organochlorine pesticide residues in aquatic organisms from Koycegiz Lagoon System, Turkey. Water, Air and Soil Pollution 121: 1-9.

Castric, J. \& Chastel, C. 1980. Isolation and characterization attempts of three viruses from European eel, Anguilla anguilla: preliminary results. Annales de l'Institut Pasteur - Virologie 131 (E): 435-448.

Claisse, D., Aranda, A. \& Auger, D. 1991. La contamination par le cadmium des poissons et crustacés de l'étang de Bages-Sigean. Ifremer report no. DRO-91-02-MR.

Corsi, I., Mariottini, M., Badesso, A., Caruso, T., Borghesi, N., Bonacci, S., Iacocca, A. \& Focardi, S. 2005. Contamination and sub-lethal toxicological effects of persistent organic pollutants in the European eel (Anguilla anguilla) in the Orbetello lagoon (Tuscany, Italy). Hydrobiologia 550: 237-249.

De Wit, R. 2011. Biodiversity of coastal lagoon ecosystems and their vulnerability to global change. In: Grillo, O. \& Venora, G., eds. Ecosystems biodiversity. Chapter 2. Croatia: In Tech Open Access Publisher, pp. 29-40.

Dekker, W. 2003. Did lack of spawners cause the collapse of the European eel, Anguilla anguilla? Fisheries Management and Ecology 10: 365-376.

Djebbari, N., Boudjadi, Z. \& Bensouilah, M. 2009. L'infestation de l'anguille Anguilla anguilla L., 1758 par le parasite Anguillicola crassus Kuwahara, Niimi \& Itagaki, 1974 dans le complexe de zones humides d'El Kala (Nord-Est algérien). Bulletin de l'Institut Scientifique, Rabat, Section Sciences de la Vie 31: 45-50.

Faliex, E. \& Morand, S. 1994. Population dynamics of the metacercarial stage of the bucephalid trematode, Labratrema Minimus (Stossich, 1887) from Salses-Leucate lagoon (France) during the cercarial shedding period. Journal of Helminthology 68: 35-40.

Fazio, G., Sasal, P., Lecomte-Finiger, R., Da Silva, C., Fumet, B. \& Moné, H. 2008. Macroparasite communities in European eels, Anguilla anguilla, from French Mediterranean lagoons, with special reference to the invasive species Anguillicola crassus and Pseudodactylogyrus spp. Knowledge and Management of Aquatic Ecosystems 06: 390-391.

Fazio, G., Sasal, P., Mouahid, G., Lecomte-Finiger, R. \& Moné, H. 2012. Swim bladder nematodes (Anguillicoloides crassus) disturb silvering in European eels (Anguilla anguilla). Journal of Parasitology 98: 695-705.

Ferrante, M.C., Clausi, M.T., Meli, R., Fusco, G., Naccari, C. \& Lucisano, A. 2010. Polychlorinated biphenyls and organochlorine pesticides in European eel (Anguilla anguilla) from the Garigliano River (Campania region, Italy). Chemosphere 78: 709-716.

Geeraerts, C. \& Belpaire, C. 2010. The effects of contaminants in European eel: a review. Ecotoxicology 19: 239-266.

van Ginneken, V., Haenen, O., Coldenhoff, K., Willemze, R., Antonissen, E., Van Tulden, P., Dijkstra, S., Wagenaar, F. \& Van Den Thillart, G. 2004. Presence of eel viruses in eel species from various geographic regions. Bulletin of the European Association of Fish Pathologists 24: 268-272.

van Ginneken, V., Ballieux, B., Willemze, R., Coldenhoff, K., Lentjes, E., Antonissen, E., Haenen, O. \& van den Thillart, G. 2005. Hematology patterns of migrating European eels and the role of EVEX virus. Comparative Biochemistry and Physiology Part C: Toxicology \& Pharmacology 140: 97102.

van Ginneken, V., Palstra, A., Leonards, P., Nieveen, M., van den Berg, H., Flik, G., Spanings, T., Niemantsverdriet, P., van den Thillart, G. \& Murk, A. 2009. PCBs and the energy cost of migration in the European eel (Anguilla anguilla L.). Aquatic Toxicology 92: 213-220.

Girard, P. 2005. Evaluation sanitaire des anguilles sur le Bassin Rhône-Méditerranée - Campagne d'Etudes 2004. Migrateurs Rhône-Méditerranée report.

Girard, P. 2007. Evaluation du statut sanitaire des civelles de Méditerranée - Campagne d'Etudes 2006. Plan Migrateurs Rhône-Méditerranée report.

Gony, S., Lecomte-Finiger, R., Faguet, D., Biagianti, S. \& Bruslé, J. 1988. Etude expérimentale de l'action du Cadmium sur les juvéniles d'anguilles: biologie du développement et cytopathologie. Océanis 14: 141-148.

Haenen, O.L.M., Lehmann, J., Engelsma, M.Y., Stürenberg, F.J., Roozenburg, I., Kerkhoff, S. \& Breteler, J.K. 2010. The health status of European silver eels, Anguilla anguilla, in the Dutch River Rhine Watershed and Lake IJsselmeer. Aquaculture 309: 15-24.

ICES. 2009. Workshop on Age Reading of European and American Eel (WKAREA), 20-24 April 2009, Bordeaux, France. No. ICES CM 2009/ACOM: 48, 66 pp.

ICES. 2012. Report of the Joint EIFAC/ICES Working Group on Eels (WGEEL), 3-9 September 2012, Copenhagen, Denmark. No. ICES CM 2012/ACOM:18. 824 pp.

Ifremer. 2008. Réseau de Suivi Lagunaire du LanguedocRoussillon: Bilan des résultats 2007. Report no. RSL-08/ 2008.

Jovanović, B., Mihaljev, Z., Maletin, S. \& Palić, D. 2011. Assessment of heavy metal load in chub liver (Cyprinidae Leuciscus cephalus) from the Nišava River (Serbia). Biologica Nyssana 2: 1-7.

Kettle, A.J., Bakker, D.C.E. \& Haines, K. 2008. Impact of the North Atlantic Oscillation on the trans-Atlantic migrations of the European eel (Anguilla anguilla). J. Geophys. Res., 113: G03004. DOI: 10.1029/2007JG000589.

Kirk, R.S., Kennedy, C.R. \& Lewis, J.W. 2000. Effect of salinity on hatching, survival and infectivity of Anguillicola crassus (Nematoda: Dracunculoidea) larvae. Diseases of Aquatic Organisms 40: 211-218.

Kuwahara, A., Niimi, A. \& Itagaki, H. 1974. Studies of a nematode parasitic in the air bladder of the eel. I. Description of Anguillicola crassa n. sp. (Philometridea, Anguillicolidae). Japanese Journal of Parasitology 23: 275-279.

Laugier, T. \& Alzieu, C. 2003. Niveaux de contamination des chairs d'anguilles de la lagune de Canet St-Nazaire (P.O.): plomb, cadmium et mercure. Ifremer report. $25 \mathrm{pp}$.

Lecomte-Finiger, R. 1985. L'âge de l'anguille européenne (Anguilla anguilla L., 1758), état actuel des connaissances et recherches nouvelles en Méditerranée. Journal of Applied Ichthyology 1: 178-192. 


\section{Silver eels quality in Mediterranean habitats}

Lefebvre, F., Contournet, P. \& Crivelli, A.J. 2002. The health state of the eel swimbladder as a measure of parasite pressure by Anguillicola crassus. Parasitology 124: 457-463.

Lefebvre, F., Acou, A., Poizat, G., Crivelli, A.J., Contournet, P., Priour, F. \& Soulas, O. 2003. Anguillicolosis among silver eels: a 2-year survey in 4 habitats from Camargue (Rhône delta, south of France). Bulletin Français de la Pêche et de la Pisciculture 368: 97-108.

Lefebvre, F., Mounaix, B., Poizat, G. \& Crivelli, A.J. 2004. Impacts of the swimbladder nematode Anguillicola crassus on Anguilla anguilla: variations in liver and spleen masses. Journal of Fish Biology 64: 435-447.

Macgregor, K., Oliver, I.W., Harris, L. \& Ridgway, I.M. 2010. Persistent organic pollutants (PCB, DDT, HCH, HCB $\& \mathrm{BDE}$ ) in eels (Anguilla anguilla) in Scotland: current levels and temporal trends. Environmental Pollution 158: 2402-2411.

Maes, G.E., Raeymaekers, J.A.M., Pampoulie, C., Seynaeve, A., Goemans, G., Belpaire, C. \& Volckaert, F.A.M. 2005. The catadromous European eel Anguilla anguilla (L.) as a model for freshwater evolutionary ecotoxicology: relationship between heavy metal bioaccumulation, condition and genetic variability. Aquatic Toxicology 73: 99-114.

Maes, G.E., Raeymaekers, J.A.M., Hellemans, B., Geeraerts, C., Parmentier, K., De Temmerman, L., Volckaert, F.A.M. \& Belpaire, C. 2013. Gene transcription reflects poor health status of resident European eel chronically exposed to environmental pollutants. Aquatic Toxicology 126: 242-255.

Mallawa, A. 1987. Dynamique des stocks exploités et halieutiques de l'anguille européenne (Anguilla anguilla L. 1758) des lagunes du Narbonnais et du Roussillon (Bages-Sigean et Canet-Saint-Nazaire), Golfe du Lion. PhD Thesis, Perpignan, France: Perpignan University, 406 pp.

Mariottini, M., Corsi, I. \& Focardi, S. 2006. PCB levels in european eel (Anguilla anguilla) from two coastal lagoons of the Mediterranean. Environmental Monitoring and Assessment 117: 519-528.

Marohn, L., Jakob, E. \& Hanel, R. 2013. Implications of facultative catadromy in Anguilla anguilla. Does individual migratory behaviour influence eel spawner quality? Journal of Sea Research 77: 100-106.

Nagel, F., Wagner, C., Hanel, R. \& Kammann, U. 2012. The silvering process of European eel (Anguilla anguilla) influences PAH metabolite concentrations in bile fluid: consequences for monitoring. Chemosphere 87: 91-96.

Oliveira Ribeiro, C.A., Vollaire, Y., Coulet, E. \& Roche, H. 2008. Bioaccumulation of polychlorinated biphenyls in the eel (Anguilla anguilla) at the Camargue Nature Reserve France. Environmental Pollution 153: 424-431.

Palstra, A.P., van Ginneken, V.J.T., Murk, A.J. \& van den Thillart, G. 2006. Are dioxin-like contaminants responsible for the eel (Anguilla anguilla) drama? Naturwissenschaften 93: $145-148$.

Palstra, A.P., Heppener, D.F.M., van Ginneken, V.J.T., Szekely, C. \& van den Thillart, G. 2007. Swimming performance of silver eels is severely impaired by the swim-bladder parasite Anguillicola crassus. Journal of Experimental Marine Biology and Ecology 352: 244-256.

Pankhurst, N.W. 1982. Relation of visual changes to the onset of sexual maturation in the European eel Anguilla anguilla (L.). Journal of Fish Biology 21: 127-140.
Persic, A., Roche, H. \& Ramade, F. 2004. Stable carbon and nitrogen isotope quantitative structural assessment of dominant species from the Vaccarès Lagoon trophic web (Camargue Biosphere Reserve, France). Estuarine, Coastal and Shelf Science 60: 261-272.

Pierron, F., Baudrimont, M., Lucia, M., Durrieu, G., Massabuau, J.C. \& Elie, P. 2008. Cadmium uptake by the European eel: trophic transfer in field and experimental investigations. Ecotoxicology and Environmental Safety 70: 10-19.

Pujolar, J., Marino, I., Milan, M., Coppe, A., Maes, G., Capoccioni, F., Ciccotti, E., Bervoets, L., Covaci, A., Belpaire, C., Cramb, G., Patarnello, T., Bargelloni, L., Bortoluzzi, S. \& Zane, L. 2012. Surviving in a toxic world: transcriptomics and gene expression profiling in response to environmental pollution in the critically endangered European eel. BMC Genomics 13: 507.

Quadroni, S., Galassi, S., Capoccioni, F., Ciccotti, E., Grandi, G., De Leo, G.A. \& Bettinetti, R. 2013. Contamination, parasitism and condition of Anguilla anguilla in three Italian stocks. Ecotoxicology 22: 94-108.

Radakovitch, O., Roussiez, V., Ollivier, P., Ludwig, W., Grenz, C. \& Probst, J.L. 2008. Input of particulate heavy metals from rivers and associated sedimentary deposits on the Gulf of Lion continental shelf. Estuarine, Coastal and Shelf Science 77: 285-295.

Ricker, W.E. 1975. Computation and interpretation of biological statistics of fish populations. Bulletin of the Fisheries Research Board of Canada 191: 382.

Robinet, T. \& Feunteun, E. 2002. Sublethal effects of exposure to chemical compounds: a cause for the decline in Atlantic eels? Ecotoxicology 11: 265-277.

Ruiz, X. \& Llorente, G.A. 1991. Seasonal variation of DDT and PCB accumulation in muscle of carp (Cyprinus carpio) and eels (Anguilla anguilla) from the Ebro Delta, Spain. Vie Milieu 41: 133-140.

Santillo, D., Johnson, P., Labunska, I. \& Brigden, K. 2005. Swimming in Chemicals: widespread presence of brominated flame retardants and PCBs in eels (Anguilla anguilla) from rivers and lakes in 10 European countries. Technical Note 12/2005/October 2005. Exeter: Greenpeace, 49 pp.

Storelli, M.M., Barone, G., Garofalo, R. \& Marcotrigiano, G.O. 2007. Metals and organochlorine compounds in eel (Anguilla anguilla) from the Lesina lagoon, Adriatic Sea (Italy). Food Chemistry 100: 1337-1341.

Sühring, R., Möller, A., Freese, M., Pohlmann, J.-D., Wolschke, H., Sturm, R., Xie, Z., Hanel, R. \& Ebinghaus, R. 2013. Brominated flame retardants and dechloranes in eels from German Rivers. Chemosphere 90: 118-124.

Sures, B. \& Knopf, K. 2004. Individual and combined effects of cadmium and 3,3 ', 4,4 ', 5-pentachlorobiphenyl (PCB $126)$ on the humoral immune response in European eel (Anguilla anguilla) experimentally infected with larvae of Anguillicola crassus (Nematoda). Parasitology 128: 445454.

Tabouret, H., Bareille, G., Mestrot, A., Caill-Milly, N., Budzinski, H., Peluhet, L., Prouzet, P. \& Donard, O.F.X. 2011. Heavy metals and organochlorinated compounds in the European eel (Anguilla anguilla) from the Adour estuary and associated wetlands (France). Journal of Environmental Monitoring 13: 1446-1456. 
Amilhat et al.

van den Thillart, G., van Ginneken, V., Korner, F., Heijmans, R., Van der Linden, R. \& Gluvers, A. 2004. Endurance swimming of European eel. Journal of Fish Biology 65: 312-318.

Viaroli, P., Lasserre, P. \& Campostrini, P. 2007. Lagoons and Wetlands. Hydrobiologia 577: 1-3.

Yildiz, S., Gurcu, B., Koca, Y.B. \& Koca, S. 2010. Histopathological and genotoxic effects of pollution on Anguilla anguilla in the Gediz River (Turkey). Journal of Animal and Veterinary Advances 9: 2890-2899.

Zhang, D.W., Wei, Y.H., Zhang, L., Luo, L.G., Chen, Y.W. \& Tu, T.H. 2012. Distribution of heavy metals in water, suspended particulate matter and sediment of poyang lake, China. Fresenius Environmental Bulletin 21: 1910-1919. 